\title{
A hearing at the Military Tribunal of Yaoundé, Cameroon: Lawyers and colonial legacies
}

\author{
Marina Brilman*
}

\section{INTRODUCTION}

On the evening of 25 April 2017, at the airport in Yaoundé, Cameroon, I had to decide whether to join the Hilton shuttle bus - escorted by a truck with armed gendarmes - or be driven to the hotel by a local contact and a driver who apparently doubled as a bodyguard. I chose the latter, thinking that a bus full of Westerners would be an easier target for Boko Haram, the terrorist group operating in Northern Cameroon. The local contact emphasised the need to stay at the Hilton, because it was the only place with sufficient security. Upon arrival, cars were searched for explosives, while guests and their luggage were screened at the entrance. Government agents sat in the lobby, hardly making any effort at being inconspicuous. They kept a close eye on who was meeting who and listened in on conversations by casually leaning against the wall or sitting at a neighbouring table.

I was in Yaoundé for a trial observation in the case of Felix Agbor Balla (a lawyer), Fontem Neba (an academic), and others. From October to December 2016, they had led protests by lawyers and teachers in the English-speaking Northwest and Southwest regions of Cameroon, particularly in the respective capital cities of Bamenda and Buea. The protests had broken out because French-speaking teachers and lawyers, trained in the French educational and civil law systems, were appointed in regions where a British educational system and common law are used. More generally, the protests reflected a growing dissatisfaction with the marginalisation of English-speaking Cameroonians, as well as their lack of political representation and participation in public life.

The division between the French and English-speaking parts of the country can be traced back to its colonial past. Cameroon was a German colony from the mid-1880s until 1914. After World War I, the League of Nations granted a Class B mandate ${ }^{1}$ to France and Britain to administer the territory; the latter being responsible for the Western regions. ${ }^{2}$ In 1960 , the French part gained independence and the République du Cameroun was constituted. ${ }^{3}$ In

\footnotetext{
* Visiting Fellow, Latin America and Caribbean Centre, London School of Economics and Political Science. Email: M.C.Brilman@1se.ac.uk. Views expressed in this essay are those of the author.

${ }^{1} \mathrm{~N}$ Berman, 'Beyond Colonialism and Nationalism? Ethiopia, Czechoslovakia, and "Peaceful Change"" 65 Nordic Journal of International Law (1996) 434, 436. Class A mandates were granted over territories that almost merited recognition as independent nations, Class B mandates over territories that allegedly required a greater measure of control by the mandated power, and Class $\mathrm{C}$ mandates were administered as part of the territory of the mandated power, under its laws.

${ }^{2}$ M-E Pommerolle \& H de Marie Heungoup, 'The "Anglophone Crisis": A Tale of the Cameroonian Postcolony' 116 African Affairs (2017) 526, 527.

${ }^{3}$ A Maja-Pearce, 'Prospects for Ambazonia' 40(20) London Review of Books (2018) 23. The French killed the leader of the independence movement, Um Nyobé, in 1958. De Gaulle sent 300 French soldiers and five battalions of African troops that carried out disappearances, public executions, and the like, to repress his followers and support Ahmadou Ahidjo, the new President appointed by France. In 2015, then-President François Hollande acknowledged the repression and said that he wanted the archives to be opened to historians. See also 'Au Cameroun, François Hollande brise un tabou', RFI Afrique, available at http://www.rfi.fr/afrique/20150703cameroun-francois-hollande-paul-biya-guerre-upc-lydienne-yen-eyoum (last visited 12 November 2018).
} 
1961, the Northern part of the territory administered by Britain voted in a plebiscite to become part of Nigeria - which had gained independence only the year before - while the South voted to become part of the newly independent Cameroon. The inhabitants of the latter hoped to preserve their cultural identity and some degree of independence under the federalist system, established in the Cameroonian Constitution of 1961. The population was asked in the plebiscite whether it wished to be 'independent by joining the Republic of Cameroon?'. ${ }^{4}$ The Southern territory, now part of Cameroon, was subsequently divided into a Northwest and Southwest region. ${ }^{5}$

In 1972, an amendment to the Constitution abolished the federal system and the country became a 'unified republic' (République unie du Cameroun) after a referendum in which an unlikely 99.7 per cent of the population voted in favour. ${ }^{6}$ In 1982, the first President of Cameroon-Amadou Ahidjo, who was put forward by France and held the position for almost 25 years - announced that he would hand over the Presidency to Paul Biya. ${ }^{7}$ In 1984, the name République du Cameroun was reintroduced and an amendment to the Constitution in 1996 established a decentralised administrative and political system. ${ }^{8}$ The Constitution currently in force, most recently amended in 2008, provides in its Article 1(2) that: "[t]he Republic of Cameroon shall be a decentralized unitary State' and that: '[ $t$ ]he official languages of the Republic of Cameroon shall be English and French, both languages having the same status'.

Both French and English-speaking Cameroonians suffer from the lack of good governance and corruption of the Biya regime, but many of the latter feel that 'there is little prospect of them ever becoming "proper" citizens' and have tried to emigrate since the late 1990s. ${ }^{9}$ This feeling of disempowerment is expressed in the poetry of English-speaking Cameroonian poets, which is 'replete with images and symbols of death, decay, emptiness, sterility and disillusionment'. ${ }^{10}$ An example of this is Bernard Fonlon's poem 'The Fear of Future Years', published two years after the North and Southwest regions became part of the independent Republic of Cameroon: ${ }^{11}$

Those hopes absurd

In youth that spurred

All shrunk like fountains dried ${ }^{12}$

This note describes the proceedings that took place on 27 April 2017 before the Military Tribunal of Yaoundé (the 'Tribunal') and events leading to the accused being tried for terrorism-related offences. It captures a particular moment in the trial and in Cameroon's recent

\footnotetext{
${ }^{4}$ Meeting with defence counsel of Balla and Neba, 10 August 2017, London.

${ }^{5}$ Pommerolle \& de Marie Heungoup (2017) 527 note 1. There are ten regions in Cameroon, with 23 million inhabitants in total. The Northwest and Southwest regions have approximately 4 million inhabitants in total.

${ }^{6}$ Ibid 528.

7 AT Ngeh, 'Language and Commitment in Anglophone Cameroonian Poetry: The Poetic Vision of Three Anglophone Cameroonian Poets' 33 South African Journal of African Languages (2013) 105, 112.

${ }^{8}$ Pommerolle \& de Marie Heungoup (2017) 530.

${ }^{9}$ MJ Alpes, 'Imagining a Future in "Bush": Migration Aspirations at Times of Crisis in Anglophone Cameroon' 21 Identities: Global Studies in Culture and Power (2014) 259, 261.

${ }^{10}$ Ngeh (2013) 105.

${ }^{11}$ Ibid 107.

${ }^{12}$ B Fonlon, 'The Fear of Future Years' (1951), quoted in ibid 108 (although he allegedly did not write these lines about the situation of the Anglophone regions in particular; rather, they convey a general sense of hopelessness).
} 
history, just before the country would slide into a non-international armed conflict. International law looms large here: in the defence team's pleadings, in the international human rights standards violated during the trial, and in the subsequent declaration of an independent state by armed separatists in October 2017.

However, perhaps most interesting during my time in Cameroon was that which remained unspoken, namely that recent events originated in the administration of territories under the League of Nations' mandate system. Colonialist thinking permeated the local lawyers' discourse and, as an international lawyer, I too found it difficult to distance myself from that colonial past. In the following, I first describe the events as they took place, before offering some reflections on the reluctant - but inescapable - involvement of (inter)national lawyers in colonial legacies.

\section{PROTESTS AND ARRESTS IN THE ENGLISH-SPEAKING REGIONS}

The protests that took place in the North and Southwest regions between October and December 2016 were met with excessive force by the police, who used tear gas to disperse the crowds. ${ }^{13}$ Approximately 100 people were arrested without being informed of the charges against them. ${ }^{14}$ Some were later released and others remain in detention. Lawyers who took part in the protests had their robes and wigs ripped off and were beaten with batons. ${ }^{15}$ Around the same time, the Cameroon Anglophone Civil Society Consortium (CACSC) was established by Balla, Neba, and others to act as an interlocutor in negotiations with the Government. However, meetings between members of the CACSC and state authorities were unsuccessful. ${ }^{16}$

In January 2017, the protesters declared 'ghost towns'; days on which lawyers and teachers went on strike and shops closed for business. On 17 January 2017, the Government declared the CACSC illegal, shut down the internet in the Northwest and Southwest regions only - thereby targeting the inhabitants of these regions specifically and infringing their right to access to information. This measure was allegedly taken to prevent the Cameroonian diaspora from spreading false information and inciting violence. At the same time, Balla, Neba and others were arrested. ${ }^{17}$ Some, whose names appeared on lists circulated by the police, were called for interrogation and went into hiding or exile. ${ }^{18}$ On 20 January 2017, the State Prosecutor (Commissaire du Gouvernment) at the Tribunal charged Balla and Neba, together with Mancho Bibixy (a radio show host who protested in a public square next to a coffin, saying his corpse would lie in it if necessary), with 'terrorism, hostility against the motherland, secession, insurrection, contempt of public authorities, and collective rebellion'; 'incitement to civil war by bringing the inhabitants of the South[west] and Northwest regions to arm themselves against other citizens'; and 'attempt[ing] to modify the constitutional laws, notably

\footnotetext{
13 Amnesty International, Cameroon, 'Excessive Force that Led to Deaths of Protesters Must Be Urgently Investigated', 9 December 2016, available at https://www.amnesty.org/en/latest/news/2016/12/cameroonexcessive-force-that-led-to-deaths-of-protesters-must-be-urgently-investigated/ (last visited 17 July 2018).

${ }^{14}$ Meeting with defence counsel, Yaoundé, April 2017.

15 Telephone conversations with two lawyers in exile, May 2017.

${ }^{16}$ Meeting with lawyer who went into hiding, Yaoundé, April 2017.

17 Amnesty International, Cameroon, 'Arrests and Civil Society Bans Risk Inflaming Tensions in EnglishSpeaking Regions', 20 January 2017, available at https://www.amnesty.org/en/press-releases/2017/01/cameroonarrests-and-civil-society-bans-risk-inflaming-tensions-in-english-speaking-regions/ (last visited 13 November 2018).

18 Telephone conversations with two lawyers in exile, May 2017.
} 
the federalist system, through violence'. ${ }^{19}$ In the same document (an ordre de mise en jugement direct), the State Prosecutor ordered their detention and submitted them to the jurisdiction of the Tribunal for judgment. ${ }^{20}$

All protesters who had been arrested were charged with the same or similar offences and tried before the Tribunal, which assumed jurisdiction pursuant to Law No 2014/028 of 23 December 2014 on the Suppression Acts of Terrorism ('Terrorism Law'). ${ }^{21}$ Almost all the offences described as 'acts of terrorism' in the Terrorism Law carry the death penalty. The Tribunal applies the Terrorism Law, the Military Justice Code, the Criminal Code, and the Criminal Procedure Code. The Military Justice Code provides that the Tribunal has jurisdiction over military offences, but also over certain offences committed by civilians, such as armed robbery. This explains the backlog of cases; it does not only hear cases of Boko Haram fighters.

\section{THE COURTROOM IN THE MILITARY COMPOUND}

On 27 April 2017, after several hearings had been adjourned, ${ }^{22}$ arguments on a bail application and - possibly - the merits of the case would be heard. By that time, the accused had been held in pre-trial detention for over three months. ${ }^{23}$ On the morning of the day of the hearing, we showed our passports to the officers standing guard outside the military compound - where the Tribunal is based - and the doors opened. Somewhat disconcertingly, the guard disappeared with our passports as the doors closed behind us. Apparently, in order to be issued with a visitor's badge, it was necessary to hand in one's passport. .

The military compound is close to Yaounde's city centre and, apart from army barracks, houses two adjoining buildings. One of these is the courtroom and in the other are the offices of the State Prosecutor, Registrar, and President of the Tribunal. After waiting outside the courtroom for a while, we were ushered into the State Prosecutor's office. Sitting at his desk, flanked by officials who looked stern but slightly curious, he informed us that he was not at liberty to discuss the case without prior authorisation from the Minister of Justice or Minister of Defence. He seemed to suggest that we should obtain such authorisation to be able to attend the hearing. However, when a lawyer who was accompanying us summarised his understanding that we were allowed to attend the hearing, but not discuss the case without prior authorisation, the State Prosecutor nodded in agreement.

It was a relief to be allowed entry, especially because military jurisdiction is often associated with trials behind closed doors. At the far end of the courtroom, there was a platform

\footnotetext{
${ }^{19}$ Ordre de mise en jugement direct, Military Tribunal of Yaoundé, 20 January 2017 (on file with author).

${ }^{20}$ Ibid.

${ }^{21}$ Although Section 3 of the law 'To Organize Military Justice and Lay Down Rules of Procedure Applicable Before Military Tribunals', Law No 2008/015, 29 December 2008, provides that military tribunals be set up in each region of the country, the same section provides that the Military Tribunal in Yaoundé may exercise its powers throughout the national territory in the event of exceptional circumstances, such as those specified in Art. 9 of the Constitution of Cameroon, which constitute a serious threat to public order or state security, or terrorism.

${ }^{22}$ The first hearing in the case of Balla and Neba was scheduled for 3 February 2017 but adjourned until 13 February 2017. During that hearing, the defence challenged the lack of adequate interpretation from French into English and the prosecution informed the Tribunal that it had not yet finalised its list of witnesses. The hearing was postponed until 23 March 2017, when the prosecution requested that case to be joined with another case against 25 defendants. The Tribunal granted the joinder on 7 April 2017, despite the defence arguing that the cases regarded facts that took place at different times and places. The hearing was again adjourned until 27 April 2017.

${ }^{23}$ The Terrorism Law provides in its section 11, entitled '[r]emand in custody', that the duration of custody is fifteen days renewable 'upon the authorisation of the State Prosecutor'. There is no maximum time limit, requirement to justify the authorisation of extension, or a decision by a judge.
} 
on which the President of the Tribunal and two assessors sat. All three judges were serving military officers, dressed in uniform. The President was a woman with the rank of Colonel and a trained lawyer. Her assessors were men, lower in rank, and at least one of them was not a lawyer. The prosecution sat to the right, together with - in this case - the legal representative of the civil party. The defence, sitting to the left, was a team of 15 people, almost all former Presidents of the Cameroon Bar Association, both English- and French- speaking. In the middle were two wooden boxes - open structures - with seats for two people each; the accused and witnesses, respectively. Behind a wooden partitioning were two rows of benches for the public.

The courtroom was filled with family members of the accused, common law lawyersrecognisable by their wigs - and civil law lawyers with a fur trimming on their black robes. The only other international representatives were from the embassies of the UK, Canada, the US, and the field office of the UN Office of the High Commissioner on Human Rights, based in Cameroon. There was no air-conditioning or ventilation and it was stifling hot. Doors were open at the side and back of the courtroom, but there was no breeze. After some time, the defendants arrived with their prison guards. First, Balla and Neba; then Bibixy and the other 25 accused. They arrived separately because Balla and Neba were held at the Prison Principale de Yaoundé, a prison for high profile offenders and those accused of terrorism, while others were held at Yaoundé's central prison.

\section{THE HEARING AT THE MILITARY TRIBUNAL}

The President of the Tribunal opened the hearing around midday by reading out the defendants' names; each one stepping forward into the wooden boxes. Balla, Neba and Bibixy in one box; the other 25 accused pressed up against each other in the other box. The absence of microphones together with the murmur from the public gallery made it hard to understand what was being said. The interpretation from French into English immediately proved problematic. The interpreter made a few hesitant attempts to translate, was corrected by the President of the Tribunal, and then abruptly stopped interpreting for the remainder of the hearing (except for submissions on the bail application, which she interpreted from English into French for the judges).

The prosecution announced that its witnesses were ready to be heard. However, after some discussion between the prosecution and lawyers of a civil party, the latter informed the Tribunal that they wished to intervene in the proceedings on behalf of victims who had been wounded in the protests. It was unclear who these victims were; their legal representative refused to identify them on security grounds. The prosecution argued that an adjournment of the hearing was necessary due to this intervention, which the defence opposed. The President of the Tribunal did not grant an adjournment and the hearing continued.

The defence team wanted to apply for bail, but the prosecution and President of the Tribunal said that they had never received the bail application. This was contested by the defence, who handed out copies so that submissions could be made. An English barrister and member of the defence team read out Balla's and Neba's cvs to argue that Cameroon should be proud of these men and not detain them as terrorists. Balla's cv included his studies at the University of Notre Dame and work for the UN, in stark contrast with the other defendants, none of whom seemed to have enjoyed a similar education. I thought this was a risky strategy in a West African country that seeks to assert its independence from colonial and Western powers, especially the British.

The submissions in English highlighted one of the main difficulties of these proceedings. When French-speaking members of the defence team, the prosecution, or the 
President of the Tribunal spoke, the 25 accused stared despondently at the floor or the ceiling, looking tired and disaffected. However, when the bail application was made in English, all heads turned as they listened intently to the lawyer speaking a language they understood.

Defence counsel argued that Balla and Neba had no previous convictions and that the judges were under oath to apply the Constitution, which refers to universal and regional human rights instruments. It also refers to the presumption of innocence, the right to a fair hearing, and the fact that treaties shall 'override national laws'. ${ }^{24}$ Subsequently, French-speaking members of the defence team presented lengthy arguments, seemingly to indulge the egos of the speakers rather than serve the interest of their clients. The latter had already been standing for three hours in the sweltering heat without food or water. Finally, after the arguments on bail had been made, defence counsel requested that the accused be seated. The 25, together with Bibixy, were led back to the benches of the public gallery by prison guards, while Balla and Neba were seated together in one of the wooden boxes. In a strange intermezzo, the prosecution took the opportunity to distribute what appeared to be chocolate bars to the judges and some members of the defence team.

Finally, a member of the defence team read out the names of the 25 others accused and said that all submissions regarding the bail application for Balla and Neba also applied to them. She argued that they were laymen, students, journalists, 'men of the street', who also had a right to be free and presumed innocent. Some had allegedly been beaten for days by the police. Since many were farmers, it was unclear why they would represent a flight risk. The prosecution did not make any substantive arguments on the bail applications, so the President of the Tribunal adjourned the hearing - again for one month, without the justification required for a repeated prolongation of pre-trial detention under universal and regional human rights law_until 24 May 2017.

\section{IN THE WAITING ROOMS OF THE OFFICIALS}

The day after the hearing, the defence counsel obtained permission for us to visit Balla and Neba at the prison where they were being held. It was a short drive through an impoverished part of town, where everything from clothing to live chickens were being sold along the roadside. We waited outside the prison gates, next to the entrance where a list of registered defence counsel was pinned to the wall. After guards inspected our passports and discussed with officials inside the prison, we were let in and crossed the courtyard.

We met the prison Director in his office, who explained that there were three different regimes for visitors: one for legal representatives, who were allowed to visit their clients during working hours if their name was on the list of counsel displayed at the entrance; another for family members and friends, who were allowed to visit prisoners with the State Prosecutor's permission; a third for international visitors or observers, who required prior authorisation from the Minister of Justice or the Minister of Defence. Since we fell into the third category, we were not allowed to meet with the prisoners and were escorted out of the building.

We returned to the centre of Yaoundé to seek permission from the Ministry of Defence but were told that we needed permission from the Ministry of Justice, since prison regimes fell under its jurisdiction. We had sought a meeting with the Minister of Justice prior to the hearing, without success. After being asked to fill out the same form twice, they informed us that the Minister would meet with us and we were led into an airconditioned waiting room. Some copies of the Government-sponsored newspaper on a coffee table and the pleasant surroundings

\footnotetext{
${ }^{24}$ Constitution of Cameroon, Art. 45 and Cameroon Penal Code, s 2 ch. 1.
} 
suggested that we were getting closer to power. However, after waiting for two hours, we were told that the Minister was 'still in another meeting' and we decided to leave.

Upon our return to the Ministry of Justice the next day, we met with the Director of the Department of Penitentiary Administration, who explained the distinction between a request to visit a prison — which fell under his jurisdiction — and a request to visit a particular prisonerwhich was decided upon by the authority under whose jurisdiction the prisoner was being detained (in this case, the Ministry of Defence). In other words, each Ministry referred to the other; we were going around in circles.

The President of the Tribunal did take time to meet with us. She received us in her office at the military compound; our seats at a distance against the wall opposite her desk. The President was friendly, but formal, and our discussion focused only on the technicalities of military jurisdiction in Cameroon. At the end of the meeting, she expressed her appreciation for our interest in how that jurisdiction operates - considering that military jurisdiction 'usually has a bad reputation' - and for trying to 'educate ourselves' instead of just writing a critical report after leaving the country. She suspected, of course, that such a report would nonetheless be written.

After reading the local newspapers to check for coverage of the hearing and meeting with a lawyer who had gone into hiding, I returned to the airport; this time in the Hilton shuttle bus. After enduring some minor abuses of power by lower level officials, a reminder of being at the mercy of bureaucrats in a dictatorship, I waited in the lounge with President Biya's portrait looking down on me. After a short stop in Douala, still Cameroonian territory, I was on my way back to Brussels.

\section{AN IMITATION OF A TRIAL; COLONIAL LEGACIES}

On the plane, I wrote the outline of the trial observation report that was subsequently published online. ${ }^{25}$ It includes a brief description of the history and context of the trial, the applicable law on military jurisdiction, the deficiencies of the Terrorism Law together with observations made during the hearing, and conclusions drawn regarding human rights violations (mainly fair trial guarantees) with reference to domestic, regional, and international law. In it, a short and hectic experience was condensed and translated into legal vocabulary. ${ }^{26}$

Specifically, the violations identified included the right to a defence (namely, access to the case file), the right to an interpreter, the right to be tried without undue delay, the right to pretrial release, and the right to physical integrity. The report also addressed the fact that the exercise of jurisdiction by a military tribunal over civilians, although in accordance with domestic law, constitutes a violation of Art. 7(1)(d) of the African Charter on Human and Peoples' Rights and Art. 14(1) of the International Covenant on Civil and Political Rights (ICCPR) insofar as such jurisdiction should be exceptional. ${ }^{27}$ and the Cameroonian authorities had not demonstrated the necessity of such jurisdiction in this case. Moreover, although serving military officers without legal training may act as judges in a court martial, in these proceedings

\footnotetext{
${ }^{25}$ M Brilman, Trial Observation Report (Cameroon), The Law Society of England and Wales, 2017, available at http://communities.lawsociety.org.uk/international/international-rule-of-law/lawyers-at-risk/trial-observationreport-cameroon/5061833. article (last visited 12 November 2018).

${ }^{26}$ D Kennedy, 'Spring Break’ 63 Texas Law Review (1985) 1387.

${ }^{27}$ Human Rights Committee, 'General Comment No 32, Article 14: Right to Equality before Courts and Tribunals and to a Fair Trial', UN Doc CCPR/C/GC/32, 23 August 2007), para. 22.
} 
this constituted a violation of the right to be tried by a 'competent, independent and impartial tribunal'. ${ }^{28}$

Although the writing of the report, its dissemination, and the way in which it was received were briefly satisfying, I was reminded of the futility of the whole exercise when a member of the defence team, visiting London for meetings, commented that 'the trial covers the real problem' - it diverts the attention away from the marginalisation of English-speaking Cameroonians. An example of such marginalisation being 'the road between Yaoundé and the Northwest [which] is tarred up to the anglophone border'. ${ }^{29}$ All this was not about the trial or these particular defendants, but about a history of state neglect that dates back to the constitution of the Republique $d u$ Cameroun. Such neglect was evident in the lack of investment in infrastructure and political will to improve the living conditionsof Englishspeaking citizens.

The statement that the trial 'covers the real problem' also suggests that Balla and Neba's trial was, in fact, an 'imitation' of a trial ${ }^{30}$ or a 'show trial', ${ }^{31}$ to the extent that it 'support[ed] political motives which had nothing to do with criminal trials' ${ }^{32}$ All parties involved in the proceedings at the Tribunal seemed to be aware that they were participating insuch a trial.Did my trial observation report not also legitimise the trial, even if it identified particular violations of rights? Did my presence during the proceedings give legitimacy to the authoritarian regime that instituted (and allegedly instructed) the military courts before which the trial was conducted?

This moral dilemma of complicity ${ }^{33}$ seems especially acute for defence counsel: is it in the best interest of the client to provide him or her with an adequate defence against the charges brought or to denounce the proceedings as illegitimate and refuse participation altogether? After all, ' $[\mathrm{t}] \mathrm{o}$ accept the terms in which the trial is conducted . . . is to already accept one interpretation of the context among those between which the political struggle has been waged'. ${ }^{34}$

This dilemma has real consequences for procedural decision-making. As a member of the defence team said: 'It is not really a trial, it is dealing with a political situation. Knowing that, the strategy is different'. Perhaps because of this, the otherwise incomprehensible decision was taken not to challenge the lack of interpretation during the hearing, even though this constituted a flagrant violation of due process. Such a challenge would probably have resulted in another adjournment, which would have prolonged the defendants' pre-trial detention. It may have been less important for the accused to understand their own counsel's submissions and the goings-on in their trial, because the outcome was already decided.

Although the colonial context was never explicitly referred to during the hearing or in meetings with officials, it constituted the backdrop to everything: the protests, the arrests, the trial. Some remarks by a fellow trial observer from the UK, including on the skin colour of someone on the defence team, served as a reminder that the idea of British Empire is still very much alive, as well as - unfortunately-statements made by Cameroonian defence counsel.

\footnotetext{
${ }^{28}$ International Covenant on Civil and Political Rights (1966) 999 UNTS 1057, Art. 14(1).

${ }^{29}$ Meeting with defence counsel, 10 August 2017, London.

${ }^{30}$ Kennedy (1985) 1407.

${ }^{31}$ M Koskenniemi, 'Between Impunity and Show Trials' 6 Max Planck Yearbook of United Nations Law (2002)

1, 7 (referring to Hannah Arendt).

32 Ibid.

${ }^{33}$ M Sfard, 'The Human Rights Lawyer's Existential Dilemma' 38 Israel Law Review (2005) 154.

${ }^{34}$ Koskenniemi (2002) 16-17.
} 
The latter said, for example, that English was the 'language [of] civilisation; that 'multiparty democracy claims started in the anglophone regions, because we were trained to claim our rights'; ${ }^{35}$ and that the common law system is obviously 'fairer' than the civil law system, its flexibility more practical in a country largely ruled by different tribal customs. ${ }^{36}$

Perhaps I was sensitive to such statements as a lawyer educated in (and, to a certain extent, partial to) the civil law system. However, what made these statements especially uncomfortable was that the local lawyer seemed to buy into a colonial discourse. In this regard, Nathaniel Berman has described the 'internalization' of 'identities projected from the metropoles', ${ }^{37}$ explaining with regard to the Algerian civil war that

the terms set by this dynamic can lead to horrors long after colonialism passes from the scene. For example, the colonial power attempted to heighten both linguistic and gender divisions within Maghrebin society in order to assimilate elements of that society to French culture. The colonial power wanted to provide a social base for the legal argument that events in North Africa were domestic French matters. ${ }^{38}$

The defence team had hired the services of a British barrister to defend the Englishspeaking accused before a French-speaking military court. In my view, this heightened the linguistic and cultural division and drew unwanted attention to a colonial past that was primarily responsible for the recent conflict. The unquestioned authority attributed to the barrister reminded me of my local contact saying that 'Cameroonians prefer Nescafé over locally harvested coffee' (referring to a belief that everything that comes from the West is better, regardless of the actual quality of the product). Moreover, the same local contact had requested that the trial observers that would attend be 'white'. Embassies normally send local staff to trial observations, but only 'white faces' in the room would make it immediately clear to the judges that international observers were present. Only the US embassy sent a white member of staff.

As an international lawyer, my reason for being in Cameroon was directly related to the consequences of a colonial past of which I too felt somehow a part. As a Dutch national, I would have felt this more acutely had the trial taken place in Suriname or Indonesia (in which case I am unsure whether my presence would have contributed to some historical understanding or been mostly prejudicial). Although the Netherlands never colonised Cameroon, I am from a former colonial power and, while in Cameroon, I represented a British institution.

\section{CONCLUSION}

As some had anticipated, on 30 August 2017 President Biya ordered the 'discontinuance of proceedings' against Balla and Neba. ${ }^{39}$ If ever there was a good example of a lack of prosecutorial independence, this was surely it. Together with approximately 53 others who had been detained after the protests, they were unconditionally released in early September

35 The Commonwealth, 'Cameroon: History', available at http://thecommonwealth.org/our-membercountries/cameroon/history (last visited 17 July 2018). Multipartyism was formally introduced in 1990, with first elections being held in 1992, after a campaign of civil disobedience that included 'ghost towns'.

${ }^{36}$ Meeting with defence counsel, August 2017, London.

${ }^{37}$ N Berman, 'In the Wake of Empire' 14 American University International Law Review (1999) 1515, 1547.

${ }^{38}$ Ibid.

${ }^{39}$ Presidency of the Republic, Republic of Cameroon, 'Violence in the North West and South West Regions: The Head of State Orders End of Court Proceedings', 30 August 2017, available at: https://www.prc.cm/en/multimedia/documents/5768-crise-nw-sw-communique-min-sgpr-arret-poursuites-en (last visited 13 November 2018). 
2017. However, the President of the Tribunal reminded them that they could be charged and detained again in future. One explanation for the release was that President Biya hoped to gain support from English-speaking Cameroonians for the Presidential elections in 2018, because it would supposedly lead to the re-opening of schools in the Northwest and Southwest. ${ }^{40}$ Otherwise, the school boycotts played into the hands of the Government which was allegedly 'delighted that a generation of anglophone children remains uneducated' so that they would not be able to formulate any claims to public participation and representation in the future. ${ }^{41}$

A few weeks after the release of Balla and Neba, protests flared up again in the Englishspeaking regions. The Government deployed soldiers on the ground, who opened fire and killed several civilians. ${ }^{42}$ Since then, separatists have declared an independent state of Ambazonia, ${ }^{43}$ military operations have been carried out in the Northwest and Southwest, and several villages have been burned down. ${ }^{44}$ Both state security forces, particularly Cameroon's Rapid Intervention Battalion - an elite army unit equipped and trained by the US and Israel ${ }^{45}$ - as well as armed separatists have killed and tortured civilians. ${ }^{46}$ The US accused the Cameroonian Government of targeted killings and arson. ${ }^{47}$ According to UN agencies, at the end of May 2018 there were 160000 internally displaced persons in Cameroon $(90$ per cent in the Southwest region) and over 21000 registered as refugees in Nigeria. ${ }^{48}$ In January 2018, Nigerian security services had abducted 12 members of the Ambazonian 'government' from a hotel in Abuja and sent them back to Cameroon, where they are now detained as terrorists,

${ }^{40}$ Meeting with defence counsel, August 2017, London.
${ }^{41}$ Ibid.
${ }^{42}$ 'At Least Eight Dead amid Cameroon Anglophone Protests', Reuters, 1 October 2017, available at
https://in.reuters.com/article/cameroon-politics/at-least-eight-dead-amid-cameroon-anglophone-protests-
idINKCN1C61B3 (last visited 17 July 2018); 'Cameroon Soldiers Shoot Independence Activists Dead', The
Guardian, 1 October 2017, available at https://www.theguardian.com/world/2017/oct/01/cameroon-soldiers-
shoot-independence-activists-dead (last visited 17 July 2018); Amnesty International, Cameroon, 'Seventeen
Killed following Protests in Anglophone Regions', 2 October 2017, available at
https://www.amnesty.org/en/press-releases/2017/10/cameroon-seventeen-killed-following-protests-in-
anglophone-regions/ (last visited 17 July 2018); UN News Centre, Cameroon, 'UN Secretary-General Urges
Dialogue to Resolve Grievances', 3 October 2017, available at https://news.un.org/en/story/2017/10/567632-
cameroon-un-secretary-general-urges-dialogue-resolve-grievances (last visited 17 July 2018).
${ }^{43}$ Maja-Pearce (2018) 23 (named after the English Baptist Missionary Society's colony for freed slaves in Ambas
Bay).
${ }_{44}$ Amnesty International, 'A Turn for the Worse: Violence and Human Rights Violations in Anglophone
Cameroon' $\quad$ available $\begin{array}{lcccr}\text { Cameroon' } & \text { 10, } & \text { available } & \text { at } \\ \text { https://www.amnesty.org/download/Documents/AFR1784812018ENGLISH.PDF (last visited } 13 & \text { November }\end{array}$ 2018).

45 'Burning Cameroon: Images You're Not Meant to See', BBC News, 25 June 2018, available at https://www.bbc.co.uk/news/world-africa-44561929 (last visited 17 July 2018).

46 'Dozens Killed in Cameroon's Restive Anglophone Region', Reuters, 26 May 2018, available at https://uk.reuters.com/article/uk-cameroon-separatists/dozens-killed-in-cameroons-restive-anglophone-regionidUKKCN1IR0GV (last visited 17 July 2018). Amnesty International (2018) 5,6, 12.

47 "US Accuses Cameroon of "Targeted Killings" of Anglophones', Reuters, 18 May 2018, available at https://www.reuters.com/article/us-cameroon-usa/u-s-accuses-cameroon-of-targeted-killings-of-anglophonesidUSKCN1IJ23Y (last visited 17 July 2018).

${ }^{48}$ United Nations Office for the Coordination of Humanitarian Affairs, 'Cameroon: Emergency Response Plan Seeks US\$15M to Reach 160,000 Internally Displaced People in the Next Three Months', 29 May 2018, available at https://www.unocha.org/story/cameroon-emergency-response-plan-seeks-us 15 m-reach-160000-internallydisplaced-people-next (last visited 17 July 2018); United Nations High Commissioner for Refugees, 'Flash Update: Cameroonian Refugee Situation 5th May-1st June 2018', 12 June 2018, available at https://data2.unhcr.org/en/documents/details/64057 (last visited 17 July 2018). 
together with 35 other refugees sent back by Nigeria. ${ }^{49}$ In May 2018, the Tribunal convicted seven anglophone activists for terrorism, insurrection, and secession; including the radio host Bibixy, previously charged and then released but now sentenced to 15 years imprisonment. ${ }^{50}$ The last time I saw him was at the military compound, where he was escorted — shackled - to the bathroom by an armed gendarme.

These events demonstrate how an initially peaceful protest by unarmed civilians escalated into a non-international armed conflict. Undoubtedly, the heavy-handed suppression of dissent, including the prosecution of civil society leaders as terrorists before military courts, contributed to the current situation. The US, Canada, France, and Britain have engaged with the Cameroonian Government diplomatically. ${ }^{51}$ However, the effectiveness of these efforts is undoubtedly hampered by the latter two states' colonial past and the interest of all to cooperate militarily with the Governments of Cameroon and Nigeria to stem the rise of Boko Haram in the region.

On 7 October 2018, Biya won the elections with 71 per cent of the vote; turnout in the anglophone regions was only 10 per cent and there were numerous allegations of fraud. ${ }^{52}$ As Biya starts his seventh term in office, he and his wife Chantal would do well to travel the untarred road from Yaoundé to the Northwest. This dusty road represents division but, at the same time, the possibility to bridge it. It is, after all, a path that connects Cameroon's citizenswhether anglophone or francophone. As local and international lawyers we surely hold more in common than the differences between common and civil law systems suggest. However, the difficulty for international lawyers is that our discipline lies at the heart of the division that sparked the conflict. International law (in this case through the League of Nations' mandate system) created - or at least contributed to - this non-international armed conflict and subsequently takes such conflict as an object of study. It creates its own subject matter, externalising conflict as if playing no part in its constitution in order to then claim legitimacy to study it 'objectively'. As practitioners and academics in international law, we have to recognise that we too are implicated in colonial legacies and consider each time whether our expertise will contribute to a post- or neo-colonial future.

\footnotetext{
${ }^{49}$ Maja-Pearce (2018) 23, 25 (Nigeria's President sought to ensure that Nigerian 'territory is not used as a staging area to destabilise another friendly sovereign country'. A territorial dispute over an archipelago was settled in Cameroon's favour by the ICJ in 2002, based on agreements entered into by colonial powers.)

50 'Cameroon Military Court Jails Anglophone Activists', BBC News, 26 May 2018, available at https://www.bbc.co.uk/news/world-africa-44263218 (last visited 13 November 2018); 'Cameroon Court Convicts Anglophone Activists of Rebellion and Terrorism', Reuters, 25 May 2018, available at https://www.reuters.com/article/us-cameroon-separatists/cameroon-court-convicts-anglophone-activists-ofrebellion-and-terrorism-idUSKCN1IQ32T (last visited 13 November 2018).

${ }^{51}$ Confirmed by the US embassy's representative in Yaoundé, who attended the hearing, as well as in meetings with the UK embassy in Yaoundé and the Foreign and Commonwealth Office.

${ }^{52}$ B Kiven, S Stone \& R Maclean, 'Biya Wins Again in Cameroon as Crackdown Disrupts Anglophone Vote', The Guardian, 22 October 2018, available at https:/www.theguardian.com/world/2018/oct/22/paul-biyacameroon-85-year-old-president-wins-re-election-landslide (last visited 12 November 2018).
} 